\title{
Correlation between thumb length on handgrip strength, hand dexterity and musculoskeletal problem among dental professional
}

Correlação entre comprimento do polegar sobre a força de preensão manual, destreza manual e problemas musculoesqueléticos entre profissionais da Odontologia

Tilak FRANCIS TG ${ }^{1}$, Siva ANANDHI ${ }^{1}$

1 -School of Physiotherapy - Vels University - OMR - Off Navalur - Thalambur campus - Chennai - 630130 - India.

\section{ABSTRACT}

Objective: The key factor for potency of the teeth is their muscular strength. The dominant hand plays an important role in most of the daily muscular activities involving dental procedure. There are many factors, which may affect the grip strength, and very few studies especially in India have shown their correlation with grip strength. Work related musculoskeletal disorders (WRMSD) are an important occupational health problem affecting dental practitioners. This study assessed the prevalence of WRMSD in dental interns in relation to the thumb length and hand grip strength. Material and Methods: Thumb length template, jammer dynamometer, nine-hole peg board, and RULA assessment. Methods: Thumb length was measured by thumb length template. Grip strength was measured by jammer dynamometer, unilateral hand finger dexterity was measured by ninehole pegboard, and work related musculoskeletal disorder was assessed by RULA. Results: Thumb length was positively correlated with grip strength and work related musculoskeletal disorder. Thumb length was negatively correlated with unilateral hand finger dexterity among dental professionals. Conclusion: Thumb length is a better predictor for measuring hand grip strength and work related musculoskeletal disorder, than unilateral hand finger dexterity.

\section{KEYWORDS}

Dental professional; Hand grip strength; Thumb length; Unilateral hand finger dexterity; Work related musculoskeletal disorder.

\section{RESUMO}

Objetivo: $\mathrm{O}$ fator chave para a potência do dentes é a força muscular dos mesmos. A mão dominante tem um papel importante nas atividades musculares diárias envolvendo procedimentos odontológicos. Há vários fatores que influenciam a força de preensão e poucos estudos, especialmente na Índia, mostra as correlações com a força de preensão. Desordens musculoesqueléticas relacionadas a trabalho (DMRT) são um importante problema ocupacional de saúde entre profissionais da Odontologia. Este trabalho verificou a prevalência de DMRTs em residentes de Odontologia e sua relação com o comprimento do polegar e a força de preensão manual. Material e Métodos: Materiais utilizados foram o gabarito de comprimento do polegar, um dinamômetro Jamar, um tabuleiro de 9 perfurações e o instrumento RULA. Métodos: O comprimento polegar foi medido pelo gabarito; a força de preensão foi medida no dinamômetro Jamer; a destreza manual unilateral foi verificada utilizando-se o tabuleiro perfurado e as desordens musculoesqueléticas associadas ao trabalhos foram determinadas pelo instrumento RULA. Resultados: O comprimento polegar apresentou correlação positiva com a força de preensão e com a presença de desordens musculoesqueléticas relacionadas ao trabalho. O comprimento polegar foi negativamente correlacionado com a destreza manual unilateral entre os profissionais da Odontologia. Conclusão: O comprimento polegar é melhor preditor para a força de preensão manual e presença de desordens musculoesqueléticas relacionas ao trabalho, do que a destreza manual unilateral.

\section{PALAVRAS-CHAVE}

Profissionais da Odontologia; Força de preensão manual; Comprimento polegar; Destreza unilateral manual; Desordem musculoesquelética relacionada ao trabalho. 


\section{INTRODUCTION}

$\mathrm{D}$ ental professionals work in a static awkward position performing procedures in a 2" x $21 / 2$ " work space, that is, patient's mouth [1].Over the years, this practice has changed from a standing to a sitting task, raising the pain in the neck and shoulder region. Human body is not maneuvered to long hour positioning. Silverstein, defined a repetitive task that involves same fundamental movements for more than $50 \%$ of the work cycle [2]. Periodontal instrumentation demands an extensive upper body mobility with muscles and tendons of forearm, hand and fingers. [3]

Strenuous work posture of dentists, with much movement of neck flexion and rotation with arms abducted on the shoulders with repetitive precise movements of the intrinsic hand muscles leads to increased levels of shoulder and neck problems [4].

A survey conducted by Mc Gill, showed that $81 \%$ of dentists surveyed have neck, shoulder, wrist and back pain [5].

An EMG study conducted by Milerand, et al, identifies the shoulder, neck and arm muscles under stress, trapezius muscles had the highest mean amplitude of $9 \%$ on the right and $7.6 \%$ on the left[6]

Morse et al. [7] reported a 37\% prevalence of neck pain and $11 \%$ prevalence of shoulder pain in dental students. Hand, wrist and arm pain are much more prevalent among dental professionals than the general public, due to the sustained grips and prolonged awkward postures dentist must employ throughout the day [8]. Repetitive forceful pinching on gripping, a sustained non-neutral position, use of vibrating tools are among the major risk factors of developing musculoskeletal disorder of hand and wrist. [2,9-11]

Musculoskeletal disorders in dentistry across the globe differ from $63 \%$ to $93 \%$. Upper limb muscles and bones are stressed more during dental surgeries than others. [12,13]

Basic surgical posture is an important threat for dental surgeons due to work demands and repetitive tasks as in scaling, root planning and uncomfortable physical body positioning leading to musculoskeletal disorders [14].

A power grip is formed with the thumb, all four fingers, and the palm of the hand achieving full hand function or even minimal grasping capability requires a working thumb in combination with the index finger. The human thumbs oppose ability and strength is fundamental to the hands interaction and manipulation of objects, $[15,16]$ hence clinicians commonly consider the thumb responsible for at least $50 \%$ of overall function. The characteristic structure of the hand is related to its function as a grasping tool. Grasping ability is made possible by the fingers. The thumb is one of the most stressfully used joints in the entire human body. As we grip onto an object, the thumb by itself will oppose the other four fingers. So in essence, the thumb must absorb nearly four times the effort than any other.

Daily functional activity requires high activity levels of flexors of forearm and hand grasping. During grasping activities, the flexor muscles of the forearm and hand create grip strength while the wrist is stabilized by extensors of the same.

Jammer dynamometer is a common tool to assess grip strength. Muscle force is measured using a hand held grip strength dynamometer. Waldo.B said grip as a force not a pressure, and is measured in pounds or kilograms. Hence hydraulic dynamometer is the best available accurate option. [17] Dexterity has been defined as the fine, voluntary used to manipulate small objects during a specific task, as measured by the time to complete the task [18] One of the most commonly used tools for assessing dexterity is the ninehole peg test. This test was originally introduced in 1971 as part of a study on strength 
and dexterity [19]. In 1985, Mathiowetz, stated the instructions for construction of the nine hole peg test, however none has ever been produced commercially, using these specifications. [20]

\section{AIM}

To determine the correlation between thumb length on handgrip strength, hand dexterity and musculoskeletal work related disorder among dental professional.

\section{Null Hypothesis}

There is no significant relationship between thumb length on grip strength, dominant hand finger dexterity and musculoskeletal work related disorder among dental professionals.

\section{MATERIALS USED}

Thumb length Template, Jammer dynamometer, Nine - hole peg board, RULA assessment.

\section{METHODOLOGY}

The study is an observational study. Sample size followed the random sampling and was comprised of 70 dentists, being 60 female dentists and 10 male dentists. The inclusion criteria were: dental professionals (Interns), age group 21 - 25 years, and subjects willing to participate in the study. Exclusion criteria were: subjects with any kind of wrist or hand injuries in the past 1 year, subjects not willing to participate in the study, subjects with previous history of fracture on upper limb, and subjects with any kind of musculoskeletal and neurological deformity in the upper limb.

\section{Thumb - length}

Thumb length is measured using template (Figure 1). Make a right angle with the thumb and pointer (index) finger. Lay the index finger against the vertical line. Extend the thumb on the ruler near to $5 \mathrm{~cm}$. Round to the nearest $5 \mathrm{~cm}$.

\section{Hand Grip Strength}

Hand grip strength is measured using a hand - held dynamometer. Participant is asked to sit in a chair with the elbow flexed to 90 degrees and the forearm in mid prone on an armrest (Figure 2). Participants are then squeezes the dynamometer. An average of 3 readings is taken [21].

\section{Dexterity}

The Nine-hole peg test is conducted on the dominant hand. One practice trial is allowed. A stopwatch records the timing in seconds (Figure 3 ).

\section{Practice Trial}

The pegs are picked using the right hand one at a time and put in the holes until they are filled (Figure 3). The pegs are then removed, one at a time again. The pegboard is stabilized with the left hand. This is a practice test.

\section{Actual Test}

The instructions are the same as the practice trial. The stopwatch starts when the patient touches the first peg. While the patient is performing the test say "Faster" when the patient places the last peg on the board instruct the patient, out again - faster" Stop the stop watch when the last peg hits the container [20].

\section{RULA}

RULA consists of three sections. The first is to recording the working posture, the second is scaring system, and the third is action level of risk and need for action to be conducted to gather assessment that is more detailed. A coding system, categorized into four levels indicates the level of intervention required to reduce the risk of injury. Activities 
Thumb-length measuring template

Make a right angle (or as clinse as you can) with your thumb and pointer finger. Lay your pointer finger against

the vertical line. Fxtend your thumb onto the centimeter ruler. Round to the nearest $5 \mathrm{~cm}$. (Turn template $180^{\circ}$ for left haind.

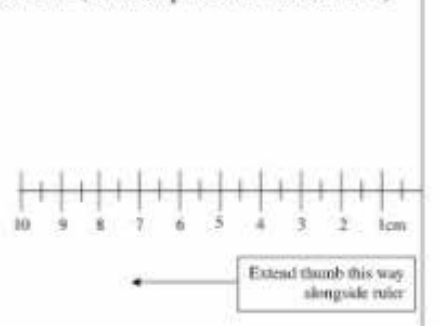

Trec poimer lange pusalled wo and aptint this

A

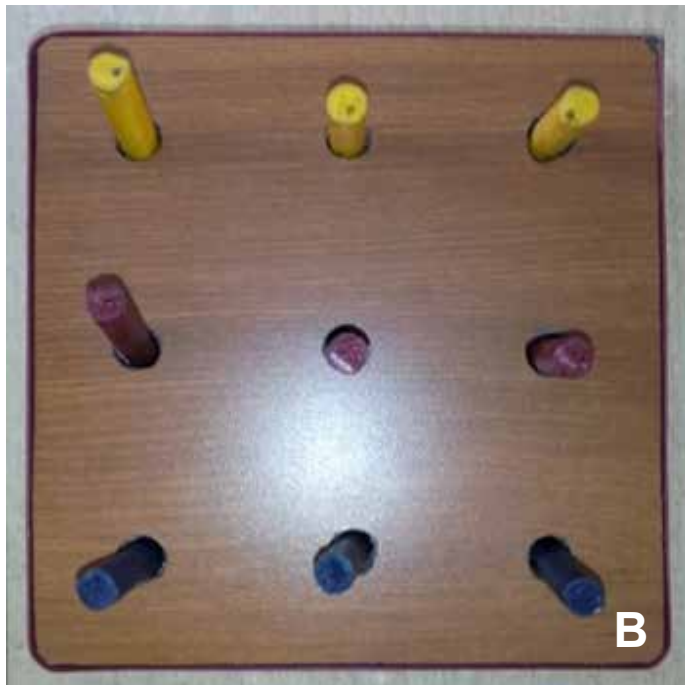

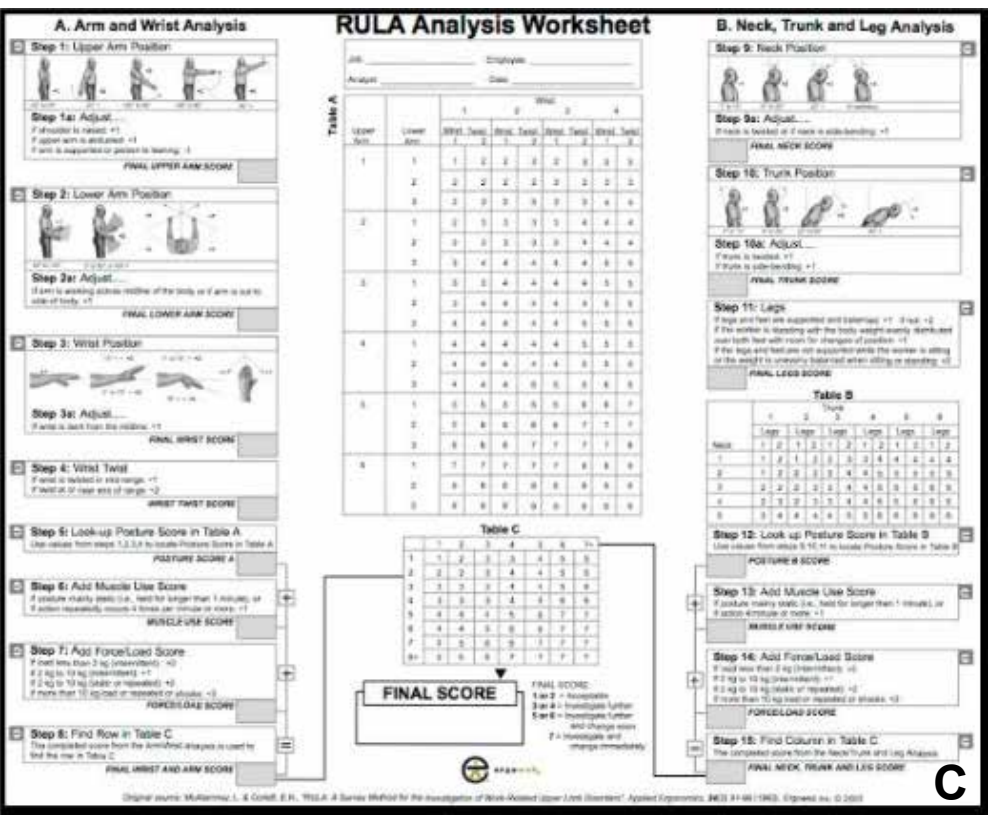

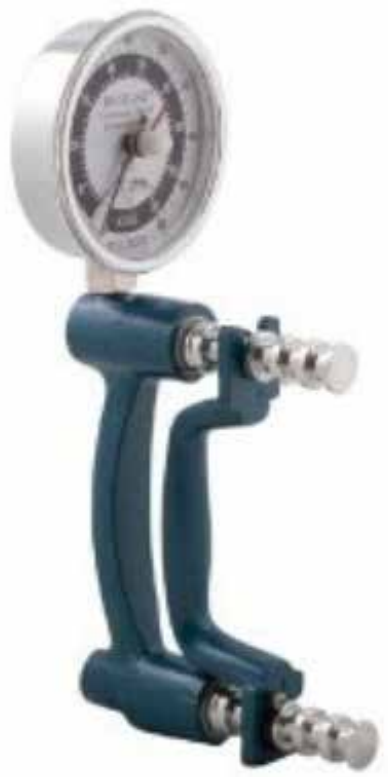

D

Figure 1 - A) Thumb length Template; B) Nine - hole peg board; C) RULA assessment; D) Jammer dynamometer.
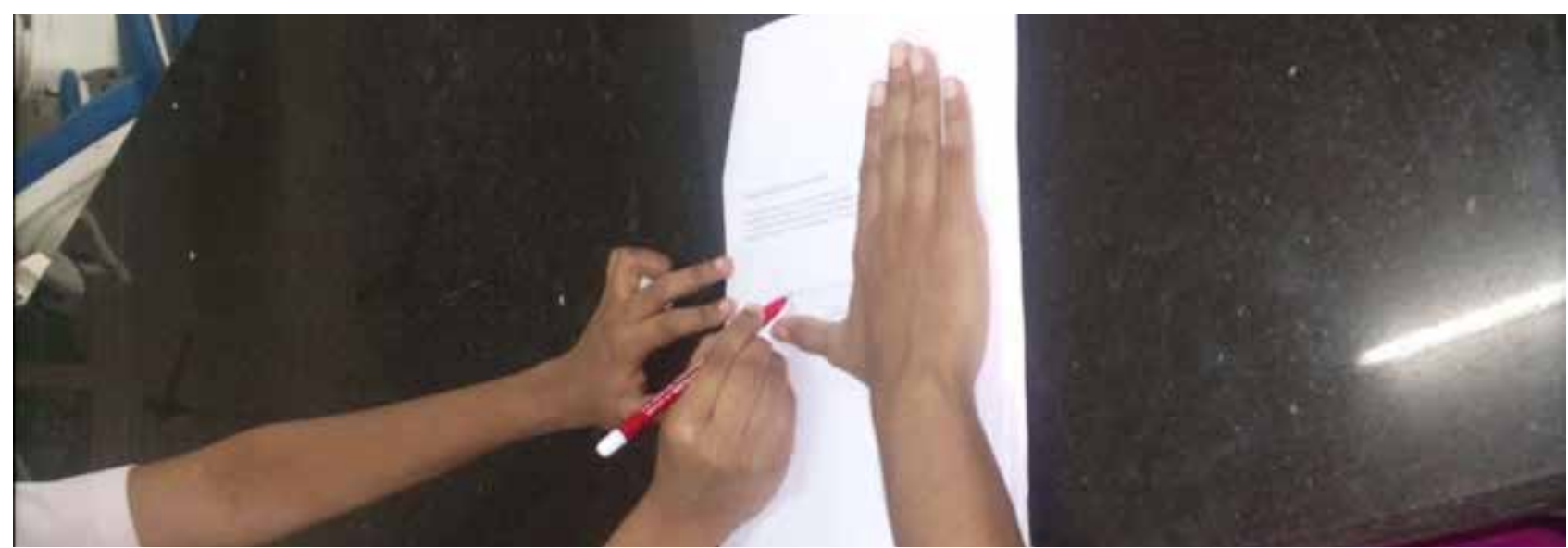

Figure 2 - Thumb length measurement. 


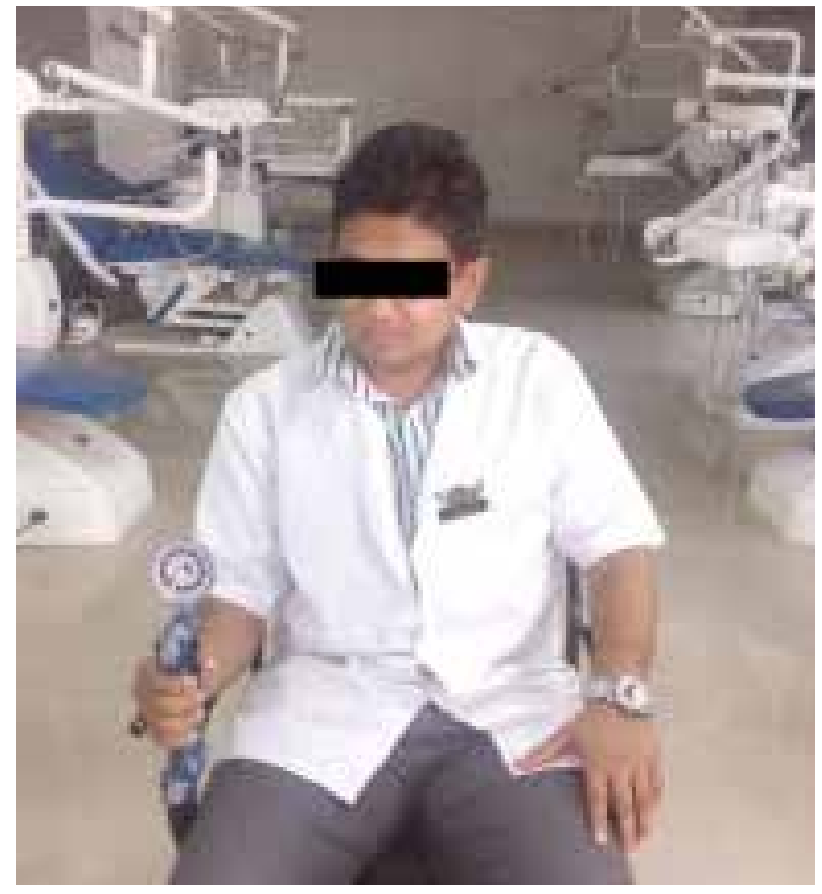

Figure $\mathbf{3}$ - Measurement of grip strength using jammer dynamometer.

using this ergonomic evaluation approach result in a risk score between one and seven where higher score signifies greater levels of apparent risk. RULA is a tool used without the need of any special equipment or investigator. It just requires a clipboard and pen and done in a simple workplace, without hindrance to the force [22].

\section{Stastical Methods}

Data is analyzed by SAS system. Regression procedure can be performed to evaluate correlation between thumb length and hand grip strength; hand dexterity and musculoskeletals among Dental professionals. Odds ratio with 95\% confidence intervals calculated as a measure of association. $\mathrm{P}<$ 0.05 is considered statistically significant.

\section{Regression Procedure} whereas:

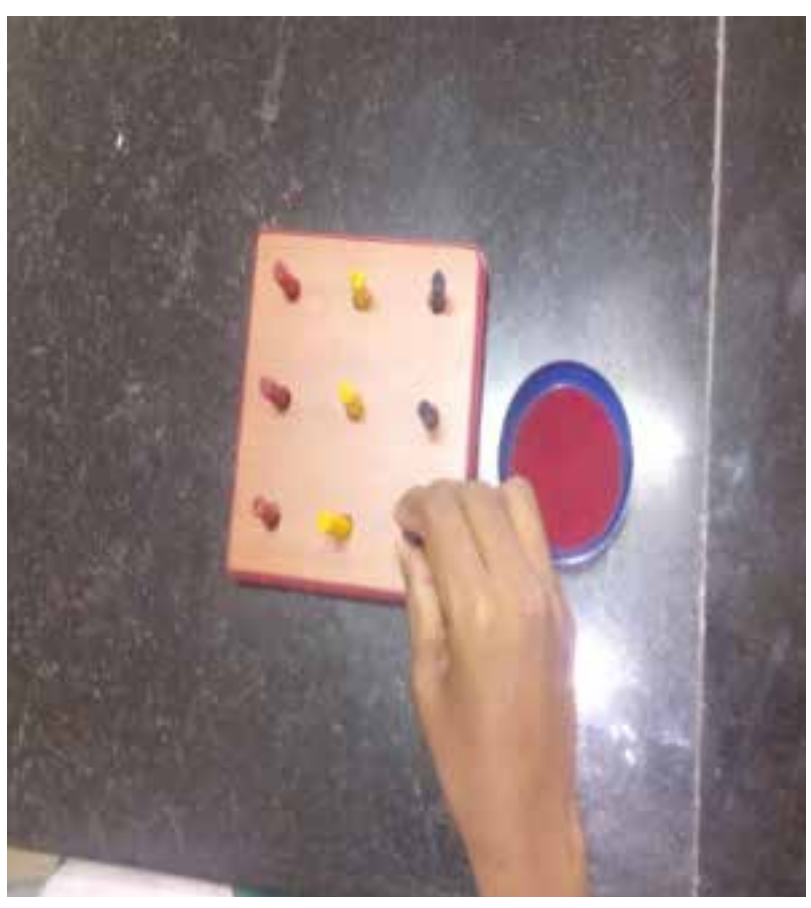

Figure 4 - Measurement as dominant hand dexterity using nine hole pegboard.

$\mathrm{Y}=$ thumb length; $\alpha=$ intercept; $\beta_{1}=$ grip strength parameter estimate; $\mathrm{X}_{1}=$ grip strength value; $\beta_{2}=$ dexterity parameter estimate; $\mathrm{X}_{2}=$ dexterity score; $\beta_{3}=$ RULA parameter estimate; $X_{3}=$ RULA score

\section{Data Analysis}

Table 1 - Analysis of variance

\begin{tabular}{|ccccccc|}
\hline \multicolumn{7}{c|}{ Analysis of Variance } \\
Source & DF & $\begin{array}{c}\text { Sum of } \\
\text { Squares }\end{array}$ & $\begin{array}{c}\text { Mean } \\
\text { Square }\end{array}$ & FValue & Pr»F \\
\hline Model & 3 & 31.76148 & 10.58716 & 23.38 & $<.0001$ \\
\hline Error & 66 & 29.88495 & 0.45280 & & \\
\hline Corrected Total & 69 & 61.64643 & & & \\
\hline
\end{tabular}

Table 2 - Mean dependent variable: thumb length the reg procedure

\begin{tabular}{|lccc|}
\hline Root MSE & 0.67291 & R-Square & 0.5152 \\
\hline Dependent Mean & 9.09286 & AdjR-Sq & 0.4932 \\
\hline CoeffVar & 7.40038 & & \\
\hline
\end{tabular}




\section{Fit Diagnostics for Thumb_length}
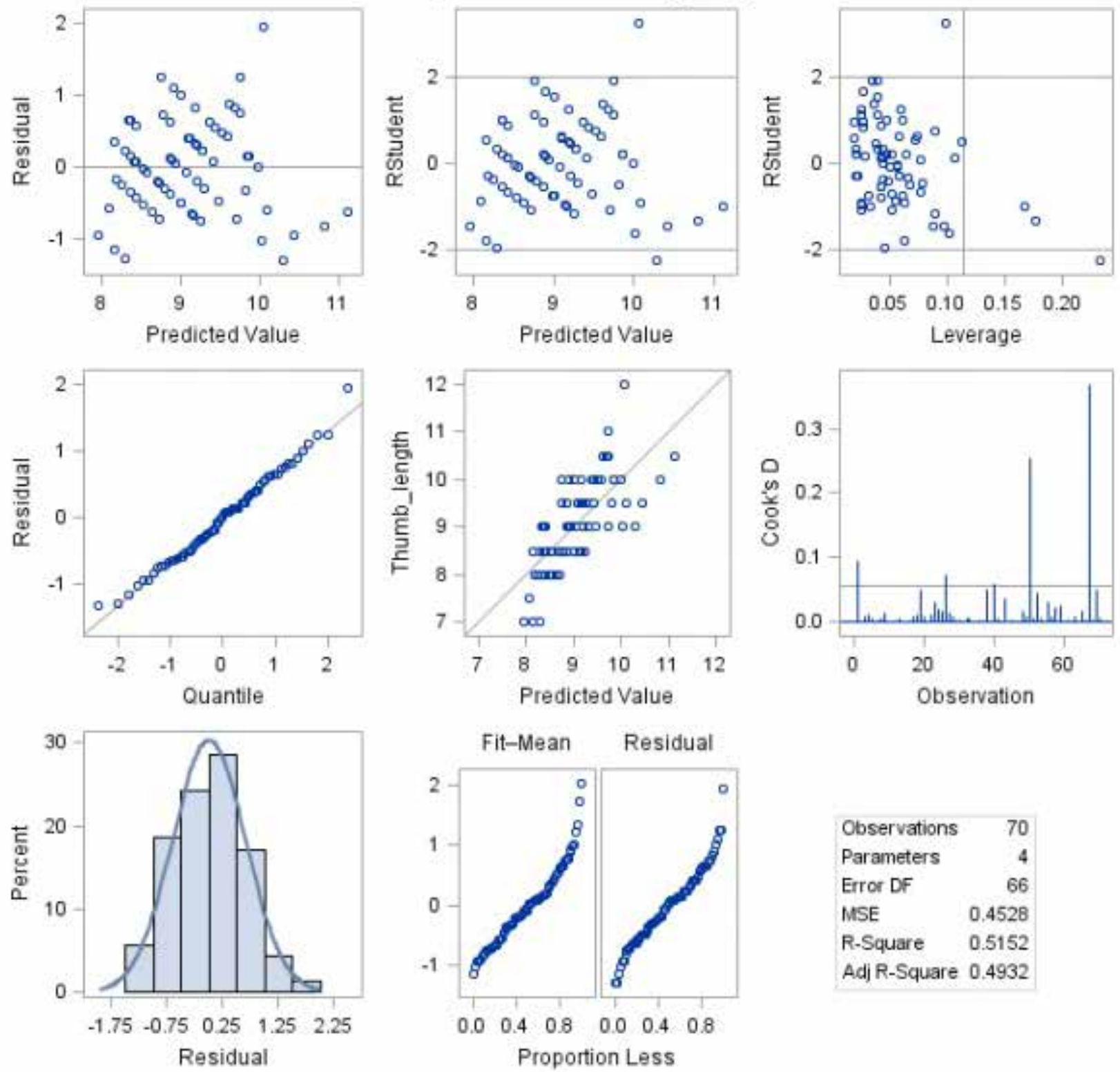

Figure 5 - Diagnostic graphs to find thumb length

\section{Parameters Estimate:}

Table 3 - Parameter estimate using regression procedure

\begin{tabular}{lcccccccc} 
& Label & DF & $\begin{array}{c}\text { Parameter } \\
\text { Estimate }\end{array}$ & $\begin{array}{c}\text { Standard } \\
\text { Error }\end{array}$ & t Value & Pr > |t| & \multicolumn{2}{c}{ 95\% Confidence Limits } \\
\hline Intercept & Intercept & 1 & 9.24166 & 0.85021 & 10.87 & $<.0001$ & 7.54416 & 10.93916 \\
Grip strength & Grip strength & 1 & 0.06859 & 0.01231 & 5.57 & $<.0001$ & 0.04401 & 0.09316 \\
Dexterity & Dexterity & 1 & -0.03266 & 0.03330 & -0.98 & 0.3304 & -0.09915 & 0.03384 \\
\hline RULA & RULA & 1 & -0.27334 & 0.08067 & -3.39 & 0.0012 & -0.43440 & -0.11228
\end{tabular}



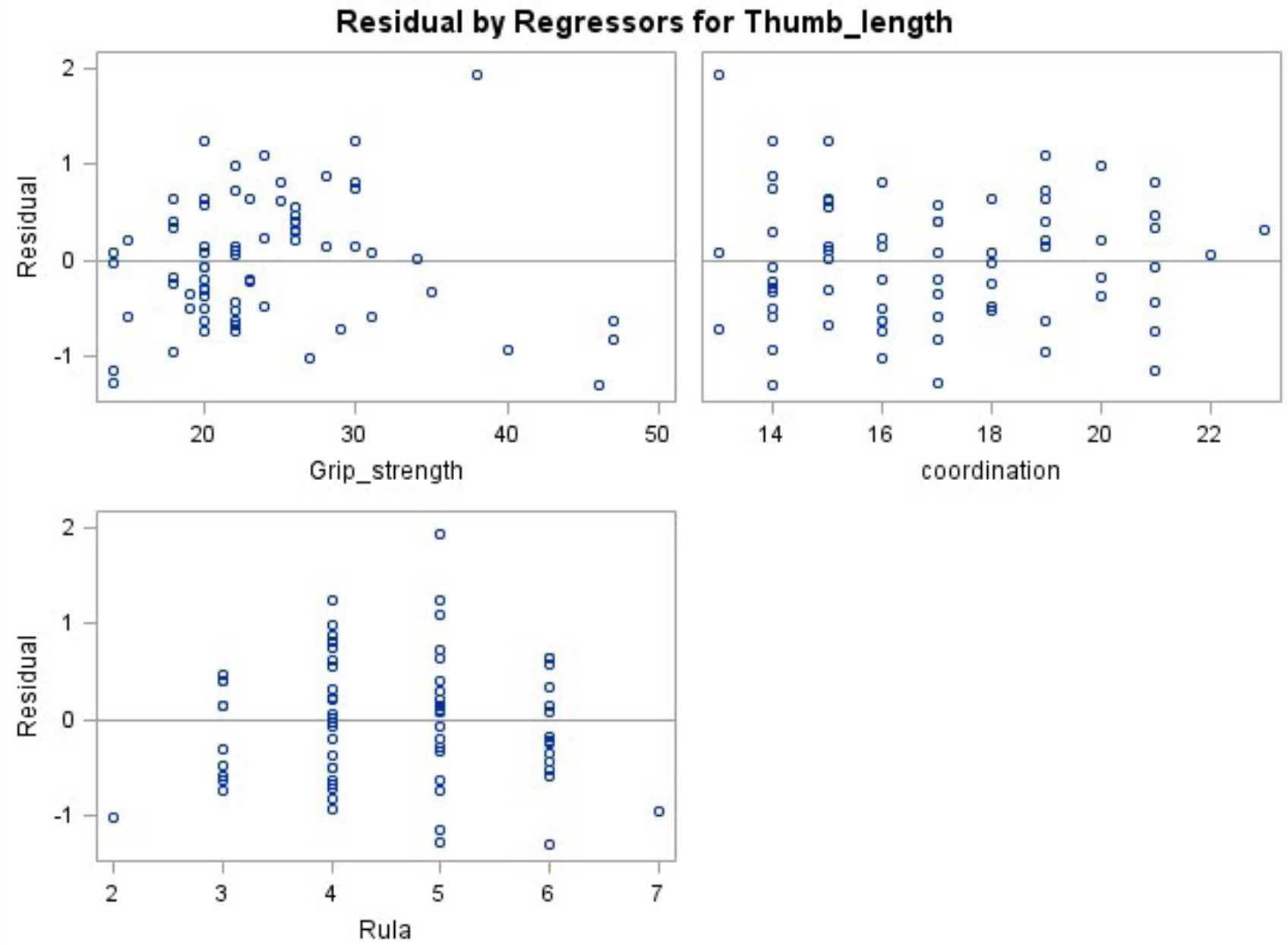

Figure 6 - Regression procedures to find thumb length

\section{RESULTS}

Thumb length and hand grip strength:

There was a statistically significant difference in thumb length and handgrip strength. The value of $\operatorname{Pr}>[\mathrm{t}]$ is < 0001 (Tables 1 and 2, Figure 4). There was a positive correlation between thumb length and handgrip strength. 95\% confidence interval of this difference from 0.04401 to 0.09316 (Table 3, Figure 5).

\section{Thumb length and hand dexterity}

There was no statistical significant difference in thumb length and hand dexterity. The value of $\operatorname{Pr}>$ [t] is 0.3304 . There was a negative correlation between thumb length and hand dexterity. 95\% confidence interval of this difference from -0.09915 to 0.03384 (Table 3, Figure 5).

\section{Thumb length and rula}

There was a statistically significant difference in thumb length and RULA. The value of $\operatorname{Pr}>$ [t] is 0.0012 . There was a positive correlation between thumb length and RULA. 95\% confidence interval of this difference from -0.43440 to 0.11228 (Table 3, Figure 5).

\section{DISCUSSION}

Static forces because of constant abnormal posture is more demanding to muscles than dynamic forces, repetitive static posture 
trigger a cascade of events leading to pain in musculoskeletal disorders. Dentists work in a static posture requiring the use of more than $50 \%$ of the body muscles to contract, inorder to resist gravity [23].

Factors such as repetitive movements, prolonged static posture and poor positioning contribute to musculoskeletal disorder [24]

Individuals with longer fingers and large hand surfaces have stronger grip power [21]. previous research studies have shown a number of factors and anthropometric variables causing these outcomes. Lee Valkov et al. [25] states that "the good functional dexterity test score in the dominant hand was predicted of a good score in the dominant hand but pinch and grip strength is poorly correlated with functional dexterity".

The objective of the present study was to evaluate the relationship between hand grip strength and thumb length, to measure unilateral finger dexterity and the extent of fine motor impairment among dentists experiencing difficulties with functional performance and to investigate the musculoskeletal work related disorders by standard questionnaire.

There were significant correlation of thumb length with hand grip strength and musculoskeletal disorders but we did not find any correlations of thumb length with hand dexterity.

The results are expected to generalize well to both genders. The findings of this study signifies the importance of the grip function, hand dexterity of unilateral hand and the musculoskeletal work related disorder during dental procedures. Because of the high prevalence of musculoskeletal disorders among dental professionals, dentist often have to consciously limit or modify grip strength and unilateral hand dexterity activities involving dental procedures.

\section{LIMITATIONS}

- Study is done with the small sample size $(\mathrm{n}=70)$.
- Short duration of the study period, involving one time observation without follow up.

\section{SUGESSTIONS}

- Further studies can be done with other anthropometric measurements.

- Further studies can be done with specific work task of the dental procedures.

- It can be done with larger sample size.

\section{CONCLUSION}

In the above summary, based on statistical analysis it was found that thumb length is positively correlated with handgrip strength, and the musculoskeletal disorders among dental professionals. The thumb length is poorly correlated with dominant hand dexterity.

\section{REFERENCES}

1. Hagberg $M$, Wegmen $\mathrm{DH}$. Prevalence rate and odds ratios of shoulder neck disease in different occupational groups. Br J Ind Med. 1987 Sep;44(9):602-10.

2. Silverstein BA, Fine LJ, ArmstromTJ, Hand wrist cumulative trauma disorder in industry. Br J Ind Med. 1986 Nov;43(11):779-84.

3. Marshall ED, Duncombe LM, Robinson RQ, Kilbreath SL. Musculoskeletal symptoms in New South Wales dentist. Aust Dent J. 1997 Aug;42(4):240-6

4. Valachi B, Valachi K. Mechanisms leading to musculoskeletal disorders in dentistry. J Am Dent Assoc. 2003 0ct;134(10):1344-50.

5. McGill SM, Hughson RL, Parks K. Lumbar erector spinae oxygenation during prolonged contractions: implications for prolonged work. Ergonomics. $2000 \mathrm{Apr}$;43(4):486-93.

6. Milerad E, Ericson M0, Nisell R, Kilbom A. Anelectromyography study of dental work. Ergonomics. 1991 Jul;34(7):953-62.

7. Morse T, Bruneau H, Michalak-Turcotte C, Sanders M, Warren $\mathrm{N}$, Dussetschleger $\mathrm{J}$, et al. Musculoskeletal disorders of the neck and shoulder in dental hygiene students. J Dent Hyg. 2007 Winter;81(1):10.

8. Hamann C, Werner RA, Franzblau A, Rodgers PA, Siew C, Gruninger S. Prevalence of carpal tunnel syndrome and median mononeuropathy among dentists. J Am Dent Assoc. 2001 Feb;132(2):163-70; quiz 223-4.

9. Dong H, Loomer P, Villanueva A, Rempel D. Pinch forces and instrument tip forces during periodontal scaling. J Periodontol. 2007 Jan;78(1):97-103.

10. Roquelaure Y, Mechali S, Dano C, Fanello S, Benetti F, Bureau D, et al. Occupational and personal risk factors for carpal tunnel syndrome in industrial workers. Scand J Work Environ Health. 1997 Oct;23(5):364-9. 
11. Gehrig NJS, Instrument grasp. In : Nield- Gehrig JS (Ed). Fundamental of periodontal instrumentation and advanced root instrumentation. 6thed. Phildelphia: Lippincott Williams and Wilkins; 2008. p.48-64.

12. Alexopoulus EC, Stathi, IC Charizani F. Prevalence of musculoskeletal disorder in dentists BMC Muskoloskelet Disord 2004; 5:16. doi:10.1186/1471-2474-5-16.

13. NasI Saraji J, Hosseini M, Shahtaheri S, Golbabaei F, Ghasemkhani $M$. Evaluation of ergonomic postures of dental professions by Rapid Entire Body Assessment (REBA). J Dent Med 2005;18(1):61-7.

14. Pollack R. Dental office ergonomics: how to reduce stress factors and increase efficiency. J Can Dent Assoc. 1996 Jun;62(6):508-10.

15. I.A Kapandjo, The physiology of the joints, upper limb, 2nded. London: E and S. Livingstone; 1970. v.1. p.182-201.

16. F.J. Bejjani and J.M.F. Landsmeer," Biomechanics of Hand" in BasicBiomechanics of the musculoskeletal system, M.Nordin and V.H.Frankel Eds.2nd ed. Philadelphia: Lea and Febiger; 1989. p.275-89.

17. Waldo B. Grip strength Testing. Strength Cond J.1996; 18(5) 32-5.

18. Backman C, Gibson SCD, Parsons J. Assessment of hand function: The relationship between pegboard dexterity and applied dexterity. Can J Occup Ther. 1992 0ct;59(4):208-13.
19. Kellor M, Frost J, Silberberg N, Iverson I, Cummings R. Hand strength and dexterity. Am J Occup Ther. 1971 Mar;25(2):77-83.

20. Mathiowetz V, Weber K, Kashman N, Volland G. Adult norms for the Nine Hole Peg Test of finger dexterity. Occup Ther J Res. 1985;5(1):24-38.

21. Hemberal M, Doreswamy V, Rajkumar S. Study of correlation between hand circumference and maximum grip strength (MGS). Natl J Physio Pharm Pharmacol 2014;4(3):195-7.

22. McAtamney L, Nigel Corlett E. RULA: a survey method for the investigation of work-related upper limb disorders. Appl Ergon. 1993;24(2):91-9

23. Ratzon NZ1, Yaros T, Mizlik A, Kanner T. Musculoskeletal symptoms among dentists in relation to work posture. Work. 2000;15(3):153-8.

24. Karwouski W, Marras WS. The occupational ergonomics hand books. Boca Raton: CRC Press; 1999. p.69-170.

25. Lee-Valkov PM, Aaron DH, Eladoumikdachi F, Thornby J, Netscher DT. Measuring normal hand dexterity values in normal 3-, 4-, and 5 -year-old children and their relationship with grip and pinch strength. J Hand Ther. 2003 Jan-Mar;16(1):22-8.

\section{Tilak Francis TG}

\section{(Corresponding address)}

MPT (Hand Conditions), PhD

Associate Professor,

School of Physiotherapy, Vels University, OMR, Off Navalur,

Thalambur campus, Chennai - 630130, India.

Date submitted: 2015 Sep 04

Email: tilakfrancis@gmail.com 